\title{
Pita Maha Social-Institutional Capital \\ (A Social Practice on Balinese Painters in 1930s)
}

I Wayan Adnyana

Indonesia Institute of the Arts Yogyakarta

email: kun_adnyana@yahoo.com

\begin{abstract}
Research Topic: Pita Maha Social-Institutional Capital (A Social Practice on Balinese Painters in 1930s) aims at describing creative waves of Balinese village youth in designing new paintings. The artwork is considered to be the latest development of classical paintings of Kamasan puppet. The pattern of development is not just on artistic technique, but also on aesthetic paradigm. Yet, the invention and development of painting concept, which were previously adopted from stylistic pattern of puppet Kamasan has successfully disseminated paintings as a medium of personal expression. The artist and patron consolidated art practice in the art function, which was well ordered and professional. Agents including palaces, Balinese and foreign painters as well as collectors and dealers were united in arts social movement, named Pita Maha. Despite the fact that Pita Maha also encompassed the sculpture, this research focuses more on the path of paintings. Socio-historical method is applied to explore the characteristics and models of social capital-institutional ideology that brought forth and commercialized paintings on Pita Maha generation. This topic is also an important part of the writer's dissertation entitled Pita Maha: Social Movement on Balinese Paintings in 1930s. The discussion on socialinstitutional capital enables expansion and exploration of a more complete socio-historical construction on Pita Maha existence. The study on social capital aspects, which embodies the initiation of Pita Maha, has constructed a tremendous growth of Balinese paintings, both in terms of aesthetic "ideology", and institutional competence of the painters.

Keywords: pita maha, social-institutional capital
\end{abstract}

\section{INTRODUCTION}

The artistic image of Balinese paintings of 1930s is substantially different from what the writer used to see in his childhood, the Kamasan puppet painting style. In every temple, the puppet painting decorated the wooden plank (parbe) section of the temple's pavilion (bale-bale) and the various ritual paraphernalia such as banners (umbul-umbul), flags (kober). Similar ones also appeared on rerajahan paintings (drawings with magical propensity used in the cremation ritual, Ngaben) and on ceremonial curtains (langse), which has been popular since the reign of Balinese King Dalem Waturenggong who ruled Bali in the $15^{\text {th }}$ Century $\mathrm{BCE}$, complete with narrative themes from the Mahabharata and Ramayana epics and the traditional mystic teachings as irreplaceable props of Balinese religious rituals.

When closely examining the personal history of Balinese painters of the 1930s, it becomes clear that they already had an advanced skill of painting Kamasan 
puppet far before the establishment of Pita Maha. The painter Anak Agung Sobrat exhibited an excellent skill and perception of painting a proportionally accurate figure of the imaginary wayang world in his 1930s works, collection of Puri Lukisan Museum. The work shows narrative heroic figures of Rama, Laksmana, Sugriwa, Hanoman of the Ramayana epic with correct proportions and composition pattern filling the entire surface of the $46.3 \times 59.1 \mathrm{Cm}$ paper, and visually already departing from the Kamasan puppet composition; and similarly, other painters such as Ida Bagus Made Poleng, I Ngendon and others whose juvenile works even already exhibited proficient technical skill and awareness of myth behind the wayang theme.

The juvenile painting talent later blossomed and found its definitive professional creative identity when the Pita Maha institution carried out its socialization process and collective creative learning. The mutual activities between Pita Maha institution and its member painters produced a creative ethic that successfully gave birth to a new Balinese painting aesthetic character.

The existence of this new Balinese painting is strongly associated with the collaborative atmosphere of Balinese painters with foreign artists, in particular Walter Spies and Rudolf Bonnet and the active roles of senior artists of the time such as Gusti nyoman Lempad, Ida Bagus Gelgel and Ida Bagus Kembeng. The two Western painters were facilitated by the Ubud palace elders namely Tjokorda Gde Raka Sukawati and his younger brother Tjokorda Gde Agung Sukawati who opened a wide interaction space for them with local artists. The establishment of Pita Maha in 1936, and Puri Lukisan Museum (inaugurated in 1956) was a "highway" and an estuary for the art social movement of 1930s. In addition the artistic gene of the Balinese also contributed to the flourishing of art in an era where geo-politically the world was in chaos due to wars.

The creative endeavor continued to progress until the artistically gifted youth matured with their painting skill, became proficient in aesthetic concepts, and grew accustomed to the creative pattern of Western painters, and thus produced an awareness to manage and to optimize the utility circuit of these creative agents. Not only painters (painting producers), but the palace institution, the Bali museum (which was already established in Denpasar), and the art market (collectors and dealers) were involved. The art social movement's arena was born out of the existing collective awareness.

In a house, which architecturally was built partially with rocks -the locals called the house the office palace-the Kawan palace Ubud of Tjokorda Gde Raka Sukawati, the Pita Maha was founded on 29 January 1936. Pita Maha accommodated all painters who throughout the 1930s conducted a constructive dialog of interacting with Bonnet and Spies.

Even to this date, the Pita Maha aesthetic continues to provide inspirations and styles to Bali's new generations, particularly painters of Ubud, Batuan, and village of Kapal, Badung. Despite technical complexities inherent to Pita Maha painting style, which requires a prolonged working hours, it still has militant followers. 
Although some of its followers jumped into another style, this painting style is still attractive. The complex birth of Pita Maha painting and its influence to the painting world of Bali generates curiosity and enthusiasm for further research.

\section{Study Formulation}

1. What is a Pita Maha social-institutional capital of 1930's?

2. How was the social-institutional capital functioning to safeguard the social practice of 1930s Balinese painters?

3. How was the social-institutional capital of 1930s Balinese painters contributing to the formulation of Pita Maha painting aesthetic "ideology" and have built a new habitus?

\section{Purpose}

Based on the formulated research questions, the purposes of this research are:

1. To analyze and understand the Pita Maha social-institutional capital of 1930s.

2. To explain comprehensively the role of the social-institutional capital in safeguarding the social practice of 1930s Balinese painters.

3. To explain the role of Pita Maha social-institutional capital in the formulation of Balinese painting aesthetic "ideology" and new habitus of 1930s.

\section{THEORY OF ART SOCIAL PRACTICE}

To obtain a comprehensive analytical result of the topic Pita Maha SocialInstitutional Capital (A Social Practice on Balinese Painters in 1930s), Bourdieu sociology theory is used as a basis, which is contextual with the field of art and socio-culture studies owing to its concepts of Fields, Capital, Habitus and Practice.

The concept of Fields by Bourdieu is defined as a series of structure manifestations of social agents involved in the art arena, which inherently contain struggles and strives to obtain a certain amount of position by the specific capital ownership and by the position already established in the specific capital structure (1993: 30). It is fitting that this concept is positioned more as a field of Forces, and "a field of struggles." Fields at all time become an objective relation system of forces between social position and symbolic points: works of art, artistic manifesto, political declaration, etc. Fields structure becomes a balanced relation between the above mentioned points and capital distribution (Harker, Mahar \& Wilkes, 1990: 8).

An understanding of Fields concept in the context of Pita Maha institution, comprehensively traces the structures of agents in the production circle of paintings in the 1930s that developed in Ubud and surrounding villages. And also analyzes the struggles and relation patterns amongst agents to access the ideal value that was collectively aspired for in the Pita Maha institution. In the creative practice agents compete by using creativity capital and relation capital they have. 
Meanwhile the practice concept conducted by agents was born within the perimeter of habitus specific. Bourdieu proposed the theory of Habitus as a set of dispositions formed and formulated through combination of objective structure and personal history. Dispositions are obtained in the various existing social positions within an arena, which carry implications of subjective adaptation for the position (Harker, Mahar \& Wilkes, 1990: 10). In brief, habitus is a product of history, produced by an individual and also by a collective; hence, the history follows the scheme produced by the history (Bourdieu, 1977: 82).

Regarding capital, Bourdieu defines it very intricately, i.e. it encompasses material things that have symbolic values, "untouched" attributes but carrying cultural significance, and also linked with cultural capital, which includes in it tastes and consumption patterns (Harker, Mahar \& Wilkes, 1990: 13). In the context of Pita Maha institution, or more specifically pertaining to arena condition of arts in the Pre Pita Maha, it became very clear that agents endowed with cultural capital and social attributes became the determining agent of the creative practice's continuity, such as the existence of the palace figure Tjokorda Gde Raka Sukawati, and also the senior local artist Gusti Nyoman Lempad who emerged as social patrons.

"the theory of the mode of generation of practice, which is the precondition for establishing an experimental science of the dialectic of the internalization of externality and the externalization of internality, or more simply, of incorporation and objectification" (Bourdieu, 1977: 72).

Practice, as Bourdieu's concept clearly analyzes, is an outcome of the dialectic dynamic between exterior internalization and interior externalization or the dialectic dynamic between the internalization of everything experienced and observed from the social actor's exterior and the expression of everything that has been internalized to be parts of the social actor (Rusdiarti, 2003 : 33). This practice theory is employed to analyze the dynamics of 1930s Balinese painters by looking at the works being produced, to show the reciprocity between the dynamic of internalization and externalization. These include self potentials, social space, and tradition heritage.

An analysis pattern that can be developed of the social-institutional capital of Pita Maha is [(habitus) (capital)] + arena = practice, where practice is a result of an accumulation of arena, habitus and capital. Bourdieu rejects the understanding of this formulation as an objectification, and encourages a dynamic effort to examine it (Mahar, Harker \& wilkes, 1990: 7). For the subject study of Pita Maha Social-Institutional Capital (A Social Practice on Balinese Painters in 1930s) this formulation is utilized more to build an articulation and analysis on conditions and facts that can be woven into the complex path of capital, arena, habitus, and also art practice. 


\section{RESEARCH METHOD}

\section{Research Form and Approach}

This study is a qualitative research using an art social history approach, in particular using Bourdieu's sociological theory, and an aesthetic study from the perspective of depth-hermeneutical by Thompson. A qualitative research according to Kirk and Muller stems from qualitative observations, which emphasizes more on natural qualitative aspects as it pertains understandings, concepts, values and characteristics inherent to the research's object (Kaelan 2005:5).

Qualitative research has minimum four philosophical foundations; one of them being truth can be obtained from capturing the phenomena or the signs that radiate from the research objects (Arikunto, 2002: 12). The writer uses purposive sampling method, i.e. deciding samples based on certain considerations that deem to give maximum data (Arikunto, 2002: 15).

\section{Source and Data Collection Technique}

This research requires many sources and data. The sources and data are 1930s Balinese paintings, interview notes, and documents like Pita Maha exhibition catalogs and the Djawa magazine (published by Java Instituut) in the 1930s and 40s that featured Pita Maha. One such Pita Maha institution exhibition catalogs is the Pita Maha exhibition in the Bandoengsche Kunstkring, 20-27 November 1938. In this exhibition a term "moderne Balische Kunst en Kunstnijverheid" was introduced to name the era of Pita Maha paintings. This catalog also included a price list as well as an admission fee of $\mathrm{f}$ 0.50. In addition, the catalog also inserted an article by H.F.E. Visser, which indicated that Pita Maha was founded on 29 January 1936 (1938: 3). Other data sources are an exhibition of Rudolf Bonnet's collections at Bataviasche Kunstkring, 29 October-20 November 1940; Pita Maha's exhibition at Bataviasche Kunstkring, 3-12 February 1939, and other Pita Maha catalogs.

Regarding data in the form of paintings, chosen were samples selected from numerous Pita Maha painters who lived wide spread in villages around Ubud, Batuan, Kamasan and Denpasar. The writer decided samples following these reasoning: first, they represent the generation of painters who were most intensive in the social arena of Pita Maha institution. And the painters certainly have worked and interacted within the social atmosphere of rural arts before interacting with Bonnet and Spies. Second, these Balinese painters later had good reputation due to their excellent works. Thus, chosen beside Lempad (Ubud, 18621978) are Ida Bagus Gelgel (Kamasan, 1900-1937), Kembeng (Tebesaya, 1897-1952), and eight other painters, namely Anak Agung Sobrat (Padangtegal, 1917-1992), 
Ida Bagus Made Poleng (Tebasaya, 1915-1999), Gusti Ketut Kobot (Pengosekan, 1917-1999), Anak Agung Meregeg (Padangtegal, 1908-2000), Ida Bagus Nadera (Tegalinggah, 1915-1997), I Reneh (Batuan, 1910-1976 ), I Gusti Made Deblog (Denpasar, 1906-1986), and I Nyoman Ngendon (Batuan, 1903-1949).

Data were obtained from direct observations, studying photographic documents, and literature reviews. And instruments to collect data include a tape recorder, a questions list, and a camera. The interview techniques include (Sutopo, 2002: 135): reflective interviews (of both the painters' subsequent generations, and art supporting institutions like museum owners), observations, and interpretation of documents.

\section{Data Analysis Technique}

The data analysis technique was done referring to the sociological approach of Bourdieu, and in the context of this research, the emphasis was on the analysis of art social-institutional capital, and the diachronic history of painting practice in Bali during pre-Pita Maha, Pita Maha, dan post-Pita Maha. The concept of art social practice pertaining to habitus, capital and arena as the practice of the agents were believed to exist by the roles of habitus, ownership of compound capitals, and arena condition.

The writing model of this art social history refers to the understanding that the 1930s temporal setting, as was the onset of the $20^{\text {th }}$ Century, was marked by a process of acceleration, thus must abandon evolution theories. Art historians were writing their response over modernism (Fernie, 1995: 16-17). The Pita Maha institution era was also faced with a movement that was not a product of slow growth, be it the emergence of a new arena, and the growth of habitus, capital, and a new pattern of art practice. Consequently, the data are verified over the encompassing sociological and aesthetic potentials.

\section{RESEARCH RESULT AND DISCUSSION}

\section{A. Beginning History: Heritage and Tradition}

The history of Balinese painting is identical with a long series of Balinese sociocultural movement in developing the mapping-formulation of aesthetic concept and visual artistic achievement. The evolution of aesthetic concept began with the official recognition of an art profession by ancient Balinese king around the $11^{\text {th }}$ Century BCE. The aesthetic concept also appeared as myths abound in Bali in legends and folklores. Meanwhile the artistic achievement that can be enjoyed as proofs of the Balinese paintings' long journey has generated several evolutionary styles: from the magic-sacred drawings to relief arts on hermitage's walls; the Klungkung classic Kamasan puppet painting era, and the Pita Maha style of 1930s.

The visual aesthetic and painting artistic technique can be stated as experiencing a progressive advancement at the closing of 1920s till the 1930s through the birth of a new art style that later popularly called the Pita Maha painting. Before delving 
into the artistic achievement and aesthetic concept of this new Balinese painting, it is important, however, to trace the art concept that was formulated by ancient Balinese king pertaining to the official recognition of painting profession, the foundation of subsequent art movements.

The ancient Balinese king, Marakata created the Batuan edict around year 944 Çaka (1022 BCE), which mentioned the profession of citrakara (masters of drawing and painting), culpika (masters of carving/sculpting), and other art profession terminologies (Goris, 1954: 97). Citrakara is a title for painter, akin to the term "artist" in the Western terminology, which refers to the notion of a "painter." The king's pronouncement of the term "Citrakara" is a proof of formal recognition for the continuity of painting profession's community.

Written on the lontar Tantu Panggelaran, Usana Jawa and Niti Praja that the gods in heaven descended to earth to teach human beings life skills as the gods were concerned to see human beings were no different from animal packs that only sleep, and eat readily available food only. Art and skills were unknown to humans. Thus, the gods took the initiative to descend to earth to teach humans various arts: Brahma taught the art of metal weaponry; Mahadewa taught silver and gold forging; Citra Gotra taught jewelry making; Bhagawan Ciptagupta taught painting; and Bhagawan Wiswakarma taught architecture (Sura et al, 2003: 109; Ramseyer, 2002: 60). Such was written on the myths how gods taught these art professions to humans. Art, thus, became a sacred entity and a communal pride, and it is sacrilegious to perform any act that defiles the art profession since art is integrated in the Balinese daily life.

The integrated relation between the king's order and the myths puts a high moral code on this profession. Artists are subjects; legal owners of art autonomy rights, and they honor the profession as life's dignity. Art embodies the breath of life; embedded as an ideology, a spiritual conviction, a path and daily discipline. So much so that Balinese of the past did not see any need to specifically define art. Even if there is an attempt to construct the meaning of arts as such, epistemologically it will be faced with a discussion of arts that intertwine with the daily life of Balinese people. The terms pertaining to arts inherited today - at least from the literatures that the writer has access to-are in the sense of art as a profession, like the terms citrakara, culpika, and others that point to a profession/ work, not to the resultant art works.

It is considerable indeed the authority held by the Citrakara group, proven by revivals in every generation. Say for example the generation of Sangging Modhara (a renown painter in Kamasan at the closing of the 19th Century) ascertaining the achievement of Kamasan puppet painting as we can see on the ceiling of the Kertagosa Hall, Klungkung. Meanwhile the generation of Ida Bagus Gelgel, Ida Bagus Kembeng at the onset of the 1930s popularized a grounded new perception to narrate epics. Next, the generation of Anak Agung Sobrat, Idan Bagus Made Poleng declared a more realistic drawing structure and showed a beginning sign myth's deconstruction. See for example how Ida Bagus Made dared to portray a 
barong heading to a river; a very peculiar approach in his time as barong is a very sacred object.

A simple summary can be made that at the onset of the second centennial of the second millennium, Bali already recognized the artist profession as an autonomous space for every holder of the profession to work accordingly. As citrakara is a label of profession, it can be understood also that art for Balinese is a totality of life's calling. Doing art is not a mere filling of one's leisure time. Art unites in the mind and totality of daily life.

A text on painting as an etching of wayang subject on a copper plaque inscription dated 1126 Çaka or 1204 BCE was found of Kehen Temple, Bangli. Etched on the plaque was Bhatara Guru Adikunti fashioning four hands surrounded by halo (prabha). In Java, an illustration of such prabha only began to appear in the Majapahit era (Goris and Dronkers. 1955: 193). Many sources mention that the etching on that very beautiful ancient inscription was the first evidence of a Balinese painting, which developed subsequently during the golden age of King Waturenggong of Klungkung in the $15^{\text {th }}$ Century as the wayang painting legacy, commonly called the classical Kamasan style. The appearance of puppet painting reached its zenith (almost in time of the Renaissance of Europe) when the Kamasan painting era with its wayang figures became an integral piece of Bali's sacred rituals history up to the $19^{\text {th }}$ century.

Technically, the Kamasan puppet painting emphasized the coloring scheme of sigarmangsi (a gradual coloring scheme around the drawing subject's boundary) with natural dyes traditionally prepared. The dominant colors are ocher, black, red, blue and white. Visually, the Kamasan puppet painting emphasizes an epic's hierarchical narrative.

The Balinese painting experienced a modern revolution in the 1930s with the appearance of Pita Maha era. Its presence was driven by painters who were united in the Pita Maha organization in 1936, Ubud. The arrival of this new Balinese painting can be said born from the three archetypal artifacts previously mentioned: the sacred and magical rajah drawings (visually surrealistic); the naturalistic gestures of reliefs on walls of Yeh Pulu hermitage; and the puppet figures of Kamasan paintings.

Apart from the ancient artifacts, the birth of the 1930s new painting was also prompted by Bali's condition as an open cultural entity, pulsating in the ongoing ethos of cultural rejuvenation. The journey of Balinese painters' each generation synthesizes the aesthetic legacy with personal exploration. They experiment with the aesthetic legacy of the past and create an authentic new achievement.

In short, the Balinese painting has evolved nearly a thousand years. It underwent a metamorphosis from an "aristocrat" entity approved by king as a form of devotion of master artisans to the God (The Supreme Creator) to a more secular rural-agrarian art, and to its most recent expression-a solitary creative experimentation. 


\section{B. Interaction As A Model of Habitus and New Social-Institutional Capital.}

The tradition of uniting in a certain community has taken place in Bali for generations, let it be based on a territory like banjar organization, based on genealogy/clan (dadia), or solidarity amongst holders of certain special talents (sekaa). The three organization models must be noted down as the social capital of how the Balinese artist generation of 1930s pioneered the establishment of a painter community.

The values and norms that exist in the Balinese society very clearly express an attitude of tolerance and openness that certainly encompass the principles of honesty and trust in a relationship, such as shown by how the painters lived side by side with Walter Spies and Bonnet in building an atmosphere of intensive socio-cultural interaction. The social capital inherited from the tradition of gathering and organizing brings forth an open and adaptive attitude toward the influences of external cultures.

Culturally, Bali started to brush with the West when the government of the Dutch East Indies pioneered tourism in 1914, where Bali was one of the must-visited destinations (Picard, 2006: 30-31). The expansion of the Dutch colonial over Bali at the end of the $19^{\text {th }}$ Century with the incidence of Puputan Jagaraga war in Buleleng, and at the onset of the $20^{\text {th }}$ Century the wars of Puputan Badung and Klungkung intensified the encounter. As Bali lost the wars, all matters pertaining to the governance administrations came under the direct control of the Dutch East Indies authority in Batavia. Via the first tourism in Bali, the colonial government also desired to preserve the unique Balinese culture; the daily religious-agrarian way of life.

But the Dutch East Indies' tourism vision of wanting preservation (more specifically isolation) of Balinese culture was clearly a trap to make Bali a static cultural space. This was non-historic looking at how Bali pulsated in the past with amalgamation of outside cultures (China, India, and Java).

The account of Western painting influencing Bali took place as a direct interactive connection. At the end of the 1920s and throughout the 1930s a unique phenomenon took place: a direct "intervention" of Western artists that would give a particular feature on subsequent developments of Balinese rural arts. The artists were Walter Spies and Rudolf Bonnet, who together with the patron from Ubud Palace, Tjokorda Gde Raka Sukawati, peddled the development toward a new Balinese painting movement.

Ubud painters such as Ida Bagus Made Poleng, Anak Agung Sobrat, Dewa Putu Bedil and others can be construed of being introduced to Western artistic views by Spies and Bonnet, whether it was on composition pattern, plasticity of forms or themes. All of these, however, through an open artistic attitude-the path of Western knowledge and ancestral artistic conviction - the Balinese painters synthesized a new creative model of modern Balinese painting. Bonnet and Spies definitely played roles on the emergence of the new paintings (Adnyana, 
2007). But ten Bonnets and ten Pita Mahas could not alone culture a new Balinese painting if it weren't for the flexibility of spirit of Balinese painters to adopt new things and willingness to change (Yuliman, 2001:301).

29 January 1936, Pita Maha, the Balinese artist organization was proclaimed with the founders being Tjokorda Gde Raka Sukawati, Tjokorda Agung Sukawati, Walter Spies, Rudolf Bonnet, and Gusti Nyoman Lempad. The name Pita Maha was taken from the Kawi language (Ancient Javanese) meaning the great ancestor, referring to the Shakti of Brahma, Saraswati, the goddess of knowledge.

Elected as the head was Ida Bagus Putu, and the secretary Tjokorda Gde Rai (an administrator from Peliatan palace). Rolf Neuhaus, a gallery and an aquarium amusement place owner in Sanur was also chosen as a secretary in 1936, and then replaced by Marianne van Wessen in 1938. The management and members accommodated all Bali social strata, including art supporting components, like galleries. In addition to painters, Pita Maha membership also included carvers and sculptors. The total number of artists was around 120-150 (Couteau, 1999: 30$31)$.

Pita Maha was soon filled with activities and became quickly popular. Couteau (1999) wrote that the first exhibition was at Sesono Budoyo Yogyakarta Hall in 1936 supported by the kunstkring. Subsequent exhibitions were in Kunstkring Batavia (1936, 1937, 1939), in Bandung (1936, 1938), in Tegal (1938), Medan, Palembang and Surabaya (1939). Exhibitions also took place abroad in prestigious places such as the Koninklijk Kolonial Instituut, the Netherlands; in Paris, New York, and Nagoya, as well as in private galleries in India, Europe and United States.

Furthermore, Bonnet took an initiative to exhibit works of Pita Maha painters to many places by bridging contact with Mrs J. de Loos-Haaxman, a commissioner of Bon van Kunstkring and with Ver v. Vrienden van Aziatische Kunst (Association of Asian Art Lovers) in the Netherlands. Through these contacts, works of Pita Maha members were exhibited at Museum Aziatische Kunst-Amsterdam; Kunstzal van Lier-Amsterdam; Pulchri Studio-Den Haag, and Calman GalleryLondon (Dermawan T, 2006: 30-31).

In addition to bridging relationship with collectors and art lovers, Pita Maha painters also received good response from art critics, a new art world as a model of new habitus. Bimbaum compared Batuan paintings with works of Douanier Rousseu and Ubud paintings with Beardsley-a painter adored by Bonnet. And in 1940 a renown art critic Jo de Gruyter wrote about the beauty of Balinese sculptures endowed with peculiarity of natural balance and stylistic feature, and wrote about the paintings being symbolic and naturalistic (Hinzler in Couteau, 1999: 31).

Names of Pita Maha members started to become known and popular: Anak Agung Sobrat, Anak Agung Meregeg, Ida Bagus Made Poleng, Gusti Ketut Kobot, Anak Agung Raka Puja, Nengah Madia, Ketut Tungeh, Dewa Putu Bedil, Wayan 
Tohjiwa and others. Their works projected both a collective identity of unique Balinese character and a stunning personal achievement.

\section{Pita Maha: Balinese Painting Social Practice}

Pita Maha was an artist organization glittered with dazzling achievements. Its membership encompassed many fine art professions in Bali. Its success should be noted down for both an ability to formulate a new concept of stylistic form in Balinese paintings and to successfully popularize numerous genuinely talented painters.

It was this first generation of Pita Maha who created the Balinese painting technique of a systematic process, which no longer followed the coloring pattern of sigarmangsi where colors are placed in gradual sequences of light to dark using natural pigments as in the Kamasan puppet painting, but instead applied a more complex and layered one, and thus more time consuming.

In general, the Pita Maha painting technique starts with sketching (ngorten), creating rough drawing narrative and composition. Next is creating drawing characters (nampad) to emphasize outlines and borders and to create the drawing's subject characters, usually done in Chinese ink. Following this is a wash technique to create light and dark (ngabur) also with Chinese ink but diluted. After dark and light contrast, white color is applied to create a sense of volume (nyelah). Next is coloring (ngewarnain) with a much diluted tempera, and then adding details (nyawi) by making definite lines on the ornaments and other parts, and finally accentuating colors on dominant parts to emphasize plasticity and lighting drama (nyenter). The color complexity and depth that viewers feel from the paintings speaks for the long and arduous procedures.

Apart from the painting technique, the most fundamental revolution was actually the birth of an awareness to introduce human figures in day to day lives as theme of paintings. Activities such as temple rituals, rice harvest in the paddy fields, traditional festival procession in villages, commotion in marketplaces, and also the lives of animals. Even if wayang or puppet figures or narrative of the wayang world once in a while still appeared as a theme, the figure's image and composition have developed toward more naturalistic ones. There was treatment toward volume, and the beginning of perspective in paintings.

In brief, it can be explained that the Pita Maha painters' achievement was no longer loyal in perpetuating the classical Kamasan wayang painting style. The theme has evolved, and the rendering of human figure's details underwent significant changes: the flat wayang figure, though still served a creative reference, was naturalized closer toward objective truth of normal human proportion.

The painting technique was also made more complex to attain plasticity of objective figuration and clamor of landscapes atmosphere. The drawing's subject composition of the new painting style completely filled the space, leaving scarcely any empty space, unlike that of the Kamasan wayang painting, which treated empty space as the sky only to be dotted with few cloud motives, and the rest 
is left white. The Pita Maha painting which is still celebrated up to this date utilizes the complexity and the crowded space as a means to narrate the entirety of Balinese nature where human beings live in harmony with the beautiful surroundings. So many fragments of lives are offered in the paintings, which render it impossible to find a single focus.

The Pita Maha painting style has existed more than 80 years and its journey continues to undergo continuous transformation to this date. Every time, a new generation is born bringing a new creative trait. Each perpetuates the style of Pita Maha in the direction of artistic dissemination, i.e. an effort of each generation to maintain as well as to spread the legacy of this 1930's painting technique to its surrounding communities as well as to informal students. This concept of legacy and expansion gives birth to custodians of this very complex painting technique.

created individually and collectively; and thus a history based upon a scheme created by a history (Bourdieu, 1977: 82). From here we can analyze that the path of creative ideas and also artistic codes that have been created by each Balinese contemporary artists for recent days, example Ketut Teja Astawa (Sanur), Wayan Sudarna Putra (Ubud), I Wayan Bendi (Batuan) and many others still offers artistic codes of Pita Maha style, can be viewed as a habitus disposition, whether they have been generated by personal history (painters' families and their surroundings) or by subconscious conditions.

\section{CONCLUSION}

The Pita Maha social-institutional capital of 1930s was the estuary of a long journey of Balinese painting history. A history that is identical to a series of sociocultural movement of Balinese people in developing the mapping-formulation of an aesthetic concept and a visual artistic achievement. The evolution of the aesthetic concept began from a formal recognition of an art profession by ancient Balinese king around the turn of the $11^{\text {th }}$ Century. The aesthetic concept also existed in myths scattered around Bali as narrative in stories and folklores. The artistic achievement that can be enjoyed as a proof of the long history of Balinese painting has given birth to several evolutionary styles from traditional magicalsacred drawings to relief arts on walls of hermitages, an era of classical Kamasan puppet painting, and the Pita Maha style of 1930s.

The visual aesthetic concept and the painting artistic technique experienced a progressive acceleration at the end of the 1920s and throughout the 1930s via the birth of a new painting style commonly called the Pita Maha painting. The Progressive movement of Pita Maha organization became a social-institutional capital; a capital that advanced from the spirit power of cooperation amongst painters, art patrons, and critics in advocating an aesthetic ideology.

The Pita Maha institution succeeded in becoming an excellent artist organization of great achievement due to the social capital inherent to this organization. The excellence can be noted down as the success to formulate a new stylistic form on 
Balinese painting and also to popularize numerous genuinely talented painters.

The Pita Maha painting style has existed more than 80 years and its journey continues to undergo continuous transformation to this date. Every time, a new generation is born bringing a new creative trait. Each perpetuates the style of Pita Maha in the direction of artistic dissemination, i.e. an effort of each generation to maintain as well as to spread the legacy of this 1930's painting technique to its surrounding communities as well as to informal students. This concept of legacy and expansion gives birth to custodians of this very complex painting technique.

\section{REFERENCES}

Adnyana, I Wayan. (2008), Ketelanjangan dalam Seni Lukis Indonesia: Perspektif Kritik Seni Rupa, Tesis (belum diterbitkan), Pasca Sarjana ISI Yogyakarta, Yogyakarta.

Arikunto, Suharsimi. (2002), Prosedur Penelitian: Suatu Pendekatan Praktek, Jakarta, Rineka Cipta.

Bourdieu, Pierre, (1977), Outline of A Theory of Practice, Cambridge University Press, Cambridge. Colombia US. (1993), The Field of Cultural Production, Colombia University Press, (1984), Distinction: A Social Critique of the Judgement of Taste, Harvard University Press, Cambridge.

Burhan, M. Agus. (2002), Seni Lukis Mooi Indie sampai Gerakan Seni Rupa Baru Indonesia, 1900-1979: Kontinuitas dan Perubahan (Desertasi), Universitas Gadjah Mada, Yogyakarta.

Couteau, Jean. 1999, Museum Puri Lukisan, Yayasan Ratna Warta, Ubud.

DermawanT, Agus. (2006), Bali Bravo: Leksikon Pelukis Tradisional Bali 200 Tahun, Panitia Bali Bangkit, Jakarta.

Gorris, Roelof. (1954), Prasasti Bali I, Lembaga Bahasa dan Budaya Universitas Indonesia, Jakarta.

Gorris, Roelof, dan P.L. Dronkers. (1954), Bali Atlas Kebudayaan, Kementrian Pendidikan dan Kebudayaan Republik Indonesia, Jakarta.

Gouda, Frances. (2007), Dutch Culture Overseas (Praktik Kolonial Di Hindia Belanda, 1900-1942), Serambi Ilmu Semesta, Jakarta.

Harrison, Lawrence E. dan Samuel P. Huntington (editor) (2006), Pembangkitan Peran Budaya: Bagaimana Nilai-nilai Membentuk Kemajuan Manusia, judul asli Culture Matter: How Values Shape Human Progress, penerj Retnowati, LP3ES, Jakarta.

Harker, Richard K., Mahar, Cheleen, \& Wilkes, Chris. (1990), An Introduction to the Work of Pierre Bourdieu: The Practice of Theory, St. Martin's Press, New York.

Holt, Claire. (1967), Art in Indonesia: Continuities and Change, Cornell University Press, Ithaca New York.

Kaelan, MS. (2005), Metode Penelitian Kualitatif Bidang Filsafat, Paradigma, Yogyakarta.

Mirsha, Gusti Ngurah Rai., AA Putra Agung, dkk., (1986), Sejarah Bali, Pemerintah Daerah Tingkat I Bali, Denpasar.

Odette Scalliet, Marie, Koos van Brakel, David van Duuren, \& Jeannette ten Kate. (1999), Pictures from the Tropics: Painting by Western Artist during the Dutch Colonial Period in Indonesia, Koninklijk Instituut voor de Tropen/Royal Tropical Institute, Amsterdam. 
Pastika, I Dewa Made., AA Gde Yugus, dan I Dewa Ayu Sri Suasmini. (2009), Kajian Estetis Seni Lukis Gaya Pita Maha (Laporan Penelitian), Fakultas Seni Rupa dan Desain ISI Denpasar.

Ramseyer, Urs. (2002), The Art and Culture of Bali, Museum der Kulturen, Basel. Rhodius, Hans, \& John Darling. (1980), Walter Spies and Balinese Art, Tropical Museum, Amsterdam.

Rusdiarti, Suma Riella. (2003), "Bahasa, Pertarungan Simbolik dan Kekuasaan", dalam majalah Basis, No. 11-12, November-Desember 2003.

Spruit, Ruud. (1995), Artis On Bali: W.O.J. Niewenkamp, Rudolf Bonnet, Walter Spies, Willem Hofker, A.J. Le Mayeur, and Arie Smit, The Pepin Press, Amsterdam.

Sura, I Gede, dan tim., (2003), Alih Aksara dan Terjemahan: Tutur Rare Angon, Siwa Guru, dan Tantu Panggelaran, Dinas Kebudayaan Provinsi Bali, Denpasar.

Vickers, Adrian, (2012), Balinese Art: Paintings and Drawings of Bali, 1800-2010, Tuttle Publishing, Singapura.

Yuliman, Sanento. (2001), Dua Seni Rupa (Sepilihan Tulisan), Ed. Asikin Hasan, Yayasan Kalam, Jakarta 